\title{
Alibi Notice Rules: The Preclusion Sanction as Procedural Default
}

\begin{abstract}
During the 1920's the alibi defense ${ }^{1}$ in criminal trials became a target of criticism as "one of the main avenues for escape of the guilty." Alibi defenses were perceived as providing a means for defendants to surprise and outmaneuver prosecutors unprepared for evidence that the accused was elsewhere when the crime occurred. ${ }^{3}$ Perhaps in response to this criticism, forty-one states have promulgated rules requiring defendants to provide notice of an alibi defense sufficiently in advance of trial to permit prosecutors to investigate the alibi; ${ }^{4}$ in 1975 , an alibi notice rule was added to the
\end{abstract}

1 "Alibi” literally means "elsewhere." Webster's Third New International DictionARY of THE ENGLish LANGUage 53 (unabr. ed. 1976). A defendant who pleads an alibi must state that, at the time the crime was committed, he was at some specific place other than the place of the crime, a place so distant that it would have been impossible for him to travel to the scene of the crime. See, e.g., People v. Terrell, 138 Cal. App. 2d 35, 52-53, 291 P.2d 155, 166 (1955) (different room in same office not enough).

2 Millar, The Modernization of Criminal Procedure, 11 J. CrIm. L. \& CRIminology 344, 350 (1920). Alibi defenses were singled out perhaps because they are the quintessential "hip pocket" defense, easily manufactured for introduction in the final hours of trial. See Epstein, Advance Notice of Alibi, 55 J. Crim. L. Criminology \& Police Sci. 29, 31 (1964). Such a manufactured alibi defense can be used to raise a reasonable doubt in the minds of the jurors. Because the prosecutor has the burden of proof beyond a reasonable doubt, even the slightest amount of alibi evidence may have a decisive impact on the case. See Flatten $\&$ Watkins, Proposed: That Texas Adopt a Statute Giving the Prosecution the Right of PreTrial Notice of the Defense of Alibi, 14 S. TEx. L.J. 1, 13-16 (1973) (arguing that an alibi notice rule leaves the defense intact for the defendant to interpose, but eliminates the abuse of fabrication).

s Surprise is far more likely in criminal than in civil trials because criminal discovery is comparatively limited. A defendant's fifth amendment privilege against self-incrimination effectively bars much discovery by the prosecution, $c f$. United States v. Garsson, 291 F. 646, 649 (S.D.N.Y. 1923) (L. Hand, J.) (discussing general procedural advantages of defendants in context of advocating absolute ban on discovery by criminal defendants), and the Supreme Court has repeatedly held that a criminal defendant has no constitutional right to discovery, see, e.g., Weatherford v. Bursey, 429 U.S. 545, 559 (1977). A number of critics have suggested that defendants should be allowed limited discovery, see, e.g., Flannery, The Prosecutor's Case Against Liberal Discovery, 33 F.R.D. 74, 78-79 (1963) (arguing that allowing liberal discovery, similar to that found in civil proceedings, to defendants is unfair to prosecutors and tempts defendants to bribe or threaten prosecution witnesses or commit perjury); but see, e.g., Pye, The Defendant's Case for More Liberal Discovery, 33 F.R.D. 82, 83 (1963) (arguing, for instance, that a defendant cannot prepare a defense unless informed of the government's case), and this position has generally held the field, see, e.g., FED. R. Crim. P. 16; IrL. Sup. CT. R. 412, 413; WIS. R. CrIM. P. 971.23-971.25.

- See infra Appendix. An alibi notice rule appeared in Scotland as early as 1887. Ep- 


\section{Federal Rules of Criminal Procedure. ${ }^{5}$}

The current federal Rule and the state alibi notice rules all require a defendant who intends to present an alibi defense to inform the prosecutor of that intention at some specified date before trial and to provide a list of alibi witnesses he intends to call. ${ }^{6}$ Under most alibi notice rules, a defendant's failure to give timely pretrial notice of an alibi defense may result in the exclusion of the defendant's alibi evidence at trial. ${ }^{7}$

The United States Supreme Court has sustained the constitutionality of alibi notice rules in general, holding that a requirement of notice by defendants does not violate the fifth amendment privilege against self-incrimination. ${ }^{8}$ The Court has explicitly reserved judgment, however, on the constitutionality of the exclusion of alibi evidence as a sanction for noncompliance with the alibi notice rule. ${ }^{9}$ In Alicea $v$. Gagnon, ${ }^{10}$ the Seventh Circuit ruled that this exclusion, sometimes called the preclusion sanction, ${ }^{11}$ in a Wisconsin alibi notice statute ${ }^{12}$ was a denial of the defendant's constitu-

stein, supra note 2 , at 29.

- Federal Rules of Criminal Procedure Amendments Act of 1975, Pub. L. No. 94-64, § 3(13), 89 Stat. 370, 372-73 (codified at Fed. R. CRIM. P. 12.1).

- Most jurisdictions also provide for other limited forms of criminal discovery, see supra note 3 , but only those rules specifically addressing the discovery of alibi information are analyzed here.

T See, e.g., ILL. Sup. CT. R. 413(d), 415(g)(i). Of the 41 states which have some form of alibi notice rule, 17 states, including Illinois, allow both the defendant's own alibi testimony as well as his witnesses' testimony to be excluded. Twenty-four states protect the defendant's testimony from exclusion, but allow the defendant's witnesses' testimony to be excluded if the defendant has not complied with the rule. See infra Appendix.

- Williams v. Florida, 399 U.S. 78, 80-86 (1970). The Court has held that due process imposes a duty on prosecutors to provide reciprocal alibi discovery to the defendants. Wardius v. Oregon, 412 U.S. 470,472 n.4 (1973).

- Wardius v. Oregon, 412 U.S. 470, 472 n.4 (1973); Williams v. Florida, 399 U.S. 78, 83 n.14 (1970); see also Taliaferro v. Maryland, 103 S. Ct. 2114, 2114-15 (1983) (White, J., joined by Brennan \& Blackmun, JJ., dissenting from denial of certiorari) (certiorari should be granted to consider whether use of the preclusion sanction to exclude the testimony of defendant's sole alibi witness violated his right to offer witnesses as guaranteed by the sixth amendment).

${ }^{10} 675$ F.2d 913 (7th Cir. 1982).

"The term "preclusion sanction" appears to have been used first in Note, The Preclusion Sanction-A Violation of the Constitutional Right to Present a Defense, 81 Yale L.J. 1342 (1972).

12 WIS. R. CRIM. P. 971.23(8). The rule provides:

Notice of alibi. (a) If the defendant intends to rely upon an alibi as a defense, the defendant shall give notice to the district attorney at the arraignment or at least 15 days before trial stating particularly the place where the defendant claims to have been when the crime is alleged to have been committed together with the names and addresses of witnesses to the alibi, if known. If at the close of the state's case the defendant withdraws the alibi or if at the close of the defendant's case the defendant does 
tional right to testify in his own behalf. ${ }^{13}$ The court endorsed the theory that Wisconsin's interest in truthful alibis and more effi: cient trials is not sufficient to justify a denial of the accused's right to present a defense. ${ }^{14}$

This comment suggests that the preclusion sanction is not a denial of a constitutional right but merely the consequence of a defendant's failure to assert the constitutional right at the appropriate point in the litigation. Part I provides an overview of the alibi notice rules in effect in state and federal courts. Part II reviews the constitutional justifications for both the alibi notice rule and the preclusion sanction, and outlines the sixth amendment challenges to the sanction. Part III defends the sanction. Its analysis balances the cost to the defendant of providing pretrial alibi notice against the benefits that notice affords the criminal justice system. Because the defendant's compliance costs are low and the benefits to the criminal justice system are great, it is appropriate to require pretrial notice as a condition to asserting the right to present an alibi defense. By failing to assert that right at the appropriate time, the defendant forfeits the right; the sanction operates merely to enforce the forfeiture. Moreover, as Part III demonstrates, none of the alternative sanctions proposed by critics of the preclusion sanction would enforce the alibi notice rule effectively. Because procedural rules that permit such forfeiture are acceptable

not call some or any of the alibi witnesses, the state shall not comment on the defendant's withdrawal or on the failure to call some or any of the alibi witnesses. The state shall not call any alibi witnesses not called by the defendant for the purpose of impeaching the defendant's credibility with regard to the alibi notice. Nothing in this section may prohibit the state from calling said alibi witnesses for any other purpose.

(b) In default of such notice, no evidence of the alibi shall be received unless the court, for cause, orders otherwise.

(c) The court may enlarge the time for filing a notice of alibi as provided in par. (a) for cause.

(d) Within 10 days after receipt of the notice of alibi, or such other time as the court orders, the district attorney shall furnish the defendant notice in writing of the names and addresses, if known, of any witnesses whom the state proposes to offer in rebuttal to discredit the defendant's alibi. In default of such notice, no rebuttal evidence on the alibi issue shall be received unless the court, for cause, orders otherwise. The Wisconsin rule is similar to most other state rules. See infra Appendix.

1s The Alicea court, in a thorough analysis discussed in greater detail infra notes 79-95 and accompanying text, held that the fifth, sixth, and fourteenth amendments provided the basis for the right to testify in one's own behalf. $675 \mathrm{~F} .2 \mathrm{~d}$ at 923 . The court acknowledged that the Supreme Court has never explicitly held that such a right exists, id. at 920 , but cited dicta from several Supreme Court opinions as supporting its conclusions and found that the majority of the lower federal courts which have considered the question have concluded that such a right exists, id. at 920-23.

14 Id. at 923-25. 
only when the defendant's compliance costs are low, Part IV discusses three proposals for reducing the compliance costs of the alibi notice rule.

\section{Federal and State Alibi Notice Rules}

Rule 12.1 of the Federal Rules of Criminal Procedure is the product of a thirty-year debate. In 1943, the Preliminary Draft of the Federal Rules of Criminal Procedure included an alibi notice rule. ${ }^{15}$ Because the Advisory Committee ${ }^{16}$ was divided on whether the prosecutor or defendant should initiate the alibi notice process, two versions of the rule were proposed to the Supreme Court with the 1944 Second Preliminary Draft. ${ }^{17}$ The Supreme Court eventually rejected both. ${ }^{18}$ In 1962 an alibi notice rule was again proposed by the Advisory Committee, ${ }^{19}$ but it died in a controversy over its constitutionality and general fairness. ${ }^{20}$ It was not until 1975 that the Supreme Court and then Congress approved an alibi notice rule. $^{21}$

15 Advisory Committee on Rulgs of Criminal Prockdurg, Fedgral Rules of Criminal Procedure: Preliminary Draft 88 (1943).

10 The rules of practice and procedure in the federal courts, including the Federal Rules of Criminal Procedure, are under constant study by Advisory Committees appointed, pursuant to 28 U.S.C. $\S 331$ (1982), by the Chief Justice of the Supreme Court through the Judicial Conference of the United States.

17 See FED. R. CRIM. P. 12.1 advisory committee note, recounting the history of the 1943 and 1944 drafts. The 1944 draft required the defendant to initiate the process by moving the courts to require the government to state with greater particularity the time and place on which it would rely; once the defendant was given this information he was required to give notice of alibi. A minority submitted an alternative proposal to the Supreme Court requiring the prosecutor to initiate the process.

13 See Federal Rules of Criminal Procedure, 327 U.S. 821 (1945) (final version of the new rules that did not include any of the alibi notice rules proposed to the Court); Proposed Amendments to Federal Rules of Criminal Procedure for the United States District Courts, 62 F.R.D. 271, 293 advisory committee note (1974) (Advisory Committee speculates that the unresolved difference of opinion "probably caused" the Court to reject both rules) [hereinafter cited as 1974 Proposed Rules]; see also Epstein, supra note 2, at 30.

1. See Preliminary Draft of Proposed Amendments: Rules of Criminal Procedure for the United States District Courts, 31 F.R.D. 665, 673-74 (1962) (proposed Rule 12A \& advisory committee note).

20 1974 Proposed Rules, supra note 18, at 293 (proposed Rule 12.1 advisory committee note). When the 1962 proposal was made, critics asserted that despite the widespread approval by state courts of alibi notice rules "such a notice invaded the fifth amendment privilege against self-incrimination and was fundamentally unfair to defendants." Everett, Discovery in Criminal Cases-In Search of a Standard, 1964 Duke L.J. 477, 497. The fear of a fifth amendment violation proved to be unfounded. See infra notes 39-46 and accompanying text (discussing Williams v. Florida, 399 U.S. 78 (1970)). Critics also expressed concern that intensive government investigation following notice of an alibi would discourage witnesses from volunteering information. Everett, supra, at 498.

21 Federal Rules of Criminal Procedure Amendments Act of 1975, Pub. L. No. 94-64, §§ 
Federal Rule of Criminal Procedure 12.1 requires the prosecutor, if he wishes to trigger the alibi notice rule, to make a written demand of the defendant concerning any alibi defense and to state the time, date, and place at which the offense was committed. ${ }^{22}$ The prosecutor is required to reciprocate by releasing alibi rebuttal information. ${ }^{23}$ The defendant and prosecutor are both under a continuing duty to provide the names and addresses of witnesses that they intend to rely on to establish the defendant's location at the time the crime was committed. ${ }^{24}$ If either party fails to comply with the rule, the judge may exclude the testimony of any alibi or

2, 3(13), 89 Stat. 370, 370, 372-73 (codified at FED. R. CRIM. P. 12.1). The 1974 Supreme Court orders promulgating the 1975 rules are reprinted at Federal RuLes 10-11 (West 1981).

22 (a) Notice by Defendant. Upon written demand of the attorney for the government stating the time, date, and place at which the alleged offense was committed, the defendant shall serve within ten days, or at such different time as the court may direct, upon the attorney for the government a written notice of his intention to offer a defense of alibi. Such notice by the defendant shall state the specific place or places at which the defendant claims to have been at the time of the alleged offense and the names and addresses of the witnesses upon whom he intends to rely to establish such alibi.

Fed. R. Crim. P. 12.1(a).

Initiation by the prosecutor is essential; one court has held that a defendant's voluntary offer of his alibi witnesses cannot substitute for the government's demand, and hence does not trigger the prosecutor's reciprocal duty to disclose alibi information as provided by FeD. R. CRIM. P. 12.1(b), quoted infra note 23. United States v. Benton, 637 F.2d 1052, 1058-59 (5th Cir. 1981).

While rule 12.1 as originally proposed by the Supreme Court required the defendant to initiate the process by informing the prosecutor of his intention to rely on an alibi defense, see 1974 Proposed Rules, supra note 18, at 292 (Proposed Rule 12.1(a) begins: "If a defendant intends to rely on the defense of alibi, he shall . . . notify the attorney for the government . . . ."), the House of Representatives created the "prosecution-triggered" process currently in effect, H.R. 6799, 94th Cong., 1st Sess. $\$ 3$ (1975); see H.R. REP. No. 247, 94th Cong., 1st Sess. 8-9 (1975), reprinted in 1975 U.S. Code CoNG. \& AD. NEws 674, 680-81. The House Committee on the Judiciary reasoned that because the prosecutor benefits from the rule, the government should bear the initial procedural burden. H.R. REP. No. 247, 94th Cong., 1st Sess. 8-9, reprinted in 1975 U.S. Code Cong. \& AD. News 680-81.

${ }^{23}$ (b) Disclosure of Information and Witness. Within ten days thereafter, but in no event less than ten days before trial, unless the court otherwise directs, the attorney for the government shall serve upon the defendant or his attorney a written notice stating the names and addresses of the witnesses upon whom the government intends to rely to establish the defendant's presence at the scene of the alleged offense and any other witnesses to be relied on to rebut testimony of any of the defendant's alibi witness.

FED. R. Crim. P. 12.1(b)

24 (c) Continuing Duty to Disclose. If prior to or during trial, a party learns of an additional witness whose identity, if known, should have been included in the information furnished under subdivision (a) or (b), the party shall promptly notify the other party or his attorney of the existence and identity of such additional witness.

Fed. R. Crim. P. 12.1(c). 
alibi-rebuttal witness except the defendant. ${ }^{25}$ For good cause shown, the trial judge may grant an exemption from any of the above rules. ${ }^{26}$ Finally, rule 12.1 renders inadmissible at trial evidence of the defendant's intention, as indicated by pretrial notice, to rely upon an alibi that is never actually presented. ${ }^{27}$

Alibi notice rules sharing many of the elements of the federal rule are in effect in forty-one states and the District of Columbia. ${ }^{28}$ The remaining nine states have no alibi notice rules. ${ }^{29}$ In twentyfour of the states with alibi notice rules and in the District of Columbia, the prosecutor must initiate the process by requesting alibi information from the defendant; ${ }^{30}$ the remaining seventeen states'

${ }^{25}$ (d) Failure to Comply. Upon the failure of either party to comply with the requirements of this rule, the court may exclude the testimony of any undisclosed witness offered by such party as to the defendant's absence from or presence at, the scene of the alleged offense. This rule shall not limit the right of the defendant to testify in his own behalf.

Fed. R. CRIM. P. 12.1(d).

26 (e) Exceptions. For good cause shown, the court may grant an exception to any of the requirements of subdivisions (a) through (d) of this rule.

FrD. R. CRIM. P. 12.1(e). The problem of defining "good cause shown" is considered infra notes $136-40$ and accompanying text.

27 (f) Inadmissibility of Withdrawn Alibi. Evidence of an intention to rely upon an alibi defense, later withdrawn, or of statements made in connection with such intention, is not admissible in any civil or criminal proceeding against the person who gave notice of the intention.

FED. R. CRIM. P. 12.1(f).

${ }^{13}$ See infra Appendix; see also Taliaferro v. State, 295 Md. 376, 386-88 \& nn.9-14, 456 A.2d 29, 35-36 \& nn.9-14, cert. denied, 103 S. Ct. 2114 (1983) (collection and discussion of state alibi notice rules); cf. Epstein, supra note 2, at 36 app. a (1964 Field Survey Questionnaire and Reponses from Prosecutors in Jurisdictions with Rules Requiring Advance Notice of Alibi); Advisory Committee on the Rules of Criminal Procedure, supra note 15, at 9697 (1947 survey of state court alibi notice rules).

10 The states without alibi notice rules are Alabama, Alaska, California, Delaware, Georgia, Kentucky, Nebraska, North Carolina, and Texas. See letters from these states' Departments of Justice (on file at The University of Chicago Law Review); see also McGuff v. State, 49 Ale. App. 88, 91-2, 268 So. 2d 868, 871 (1972), cert. denied, 289 Ala. 746, 268 So. 2d 877 (1972) (confirming that Alabama does not have an alibi notice rule). At least one state attempts to provide liberal protection of the prosecution against surprise from an unanticipated alibi defense despite the absence of an alibi notice rule by authorizing continuances whenever a defendant's witness presents alibi testimony. The rule also provides that if only the defendant's testimony is at issue, the continuance shall not exceed one day. See CaL. Penal Code $\$ 1051$ (West 1984). The original version of the statute was directed specifically to alibi witnesses. See An Act to Add Section 1051 to the Penal Code, Relating to Criminal Procedure, ch. 551, $\S 1,1980$ Cal. Stat. 1534, amended by An Act to Amend Section 1051 of, and Add Section 1102.5 to, the Penal Code, Relating to Discovery, ch. 1249, § 1, 1982 Cal. Stat. 6688, amended by An Act to Amend Section 1051 of the Penal Code, Relating to Discovery, ch. 782, § 1, 1983 Cal. Stat. 4268. The 1982 amendment broadened the rule to include all defense witnesses, and the 1983 amendment limited the continuance for a defendant's testimony to one day.

so See Ark. R. CrIm. P. 18.3; Colo. R. CRIM. P. 12.1; Conn. Super. Ct. R. §§ 762-767; 
rules require the accused to raise the alibi issue during the pretrial period. ${ }^{31}$ In most states, preclusion of alibi or alibi-rebuttal evidence is the sole sanction for failure by either the accused or the prosecutor to adhere to the notice requirement. ${ }^{32}$ Twenty-three of those states except the defendant's own alibi testimony, either explicitly by statute ${ }^{33}$ or by judicial interpretation. ${ }^{34} \mathrm{~A}$. number of state rules permit alternate sanctions, ${ }^{35}$ most commonly continuances to permit further investigation by the opposing party ${ }^{36}$ and contempt for willful violation of the rule. ${ }^{37}$ In every state the exercise of any sanction is at the discretion of the trial court. ${ }^{38}$

D.C.R. Crim. P. 12.1; Fla. R. Crim. P. 3.200; Idaho Code $\$ 19-519$ (1) (1979); Llt. Sup. CT. R. 413(d); La. Code Crim. Proc. Ann. art. 727(A) (West 1981); Me. R. Crim P. 16A(b); MD. Ann. Code 9B Rule 741(d)(3); Mass. R. Crim. P. 14(b)(1)(A); Minn. R. Crim. P. 9.03-.03; Miss. Uniform Cir. CT. R. 4.07; Mo. R. CRIm. P. 25.05(A)(5); N.J.R. Crim. Prac. 3:11-1; N.M.R. Crim. P. 32(a); N.Y. CRIM. Proc. LAW § 250.20(1) (McKinney 1982); R.I.R. CRIM. P. 16(c) (if defendant requests discovery); S.C.R. of Practice in Cir. CT. 103(e)(1); S.D. Codified Laws ANn. § 23A-9-1 (1979) (Rule 12.1(a)); Tenn. R. CRim. P. 12.1(a); VA. Sup. CT. R. 3A:14(c)(2) (if defendant requests discovery); WASH. R. CrIM. P. 4.7(b)(2); W. VA. R. CRIM. P. 12.1(a); Wyo. R. CRIM. P. 16.1(a).

31 See Ariz. R. Crim. P. 15.2(b); Hawait R. Penal P. 12.1(a); Ind. Code Ann. § 35-36-41 (Burns 1983); Iowa R. Crim. P. 10(11a); Kan. Stat. Ann. § 22-3218(1) (1981); Mich. Comp. Laws Ann. § 768.20(1) (West 1982); Mont. Code AnN. § 46-15-301(2) (1983); Nev. Rev. Stat. § 174.087(1) (1981); N.D.R. Crim. P. 12.1(a); N.H. Super CT. R. 100; Ohio R. Crim. P. 12.1; Okta. Stat. AnN. tit. 22, \& 585 (West 1969); OR. Rev. Stat. \$ 135.455 (1981); Pa. R. Crim. P. 305(C)(1)(a); Utah Code ANN, § 77-14-2(1) (1982); VT. R. CRIM. P. 12.1(a); Wis. R. Crim. P. 971.23(8)(a).

s2 See, e.g., D.C.R. Crim. P. 12.1(d); WIs. R. CrIm. P. 971.23(8)(b), (d); infra Appendix.

ss See Conn. Super. CT. R. § 762-767; D.C.R. Crim. P. 12.1(d); Fla. R. Crim. P. 3.200; Hawail R. Penal P. 12.1(e); Idaho Code § 19-519(4) (1979); Iowa R. Crim. P. 10(11d); Kan. Stat. Ann. § 22-3218(1) (1981); La. Code Crim. Proc. Ann. art. 727(D) (West 1981); Mass. R. CRIM. P. 14(b)(1)(D); Miss. UnIform CIR. CT. R. 4.07; Nev. REv. Stat. § 174.087(4) (1981); N.H. Sup. CT. R. 100; N.M.R. CRIM. P. 32(c); N.D.R. CRIM. P. 12.1(c); PA. R. CRIM. P. 305(c)(1); S.C.R. of Practice in Cir. Cr. 103(e)(4); S.D. Codfried Laws ANn. § 23A-9-4 (1979) (Rule 12.1(d)); TENn. R. CRIM. P. 12.1(d); UtAh Code AnN. § 77-14-2(3) (1982); W. VA. R. CrIM. P. 12.1(d); Wyo. R. CRIM. P. 16.1(d). In Vermont, the reporter's notes appended to the rule indicate that it should be read as excluding the defendant's testimony from the sanction. VT. R. Crim. P. 12.1 reporter's notes.

s4 See, e.g., People v. Merritt, 396 Mich. 67, 83-88, 238 N.W.2d 31, 38-41 (1976); People v. Rakiec, 289 N.Y. 306,45 N.E.2d 812 (1942).

ss In Maine, for example, the response to the defendant's violation of the rule is simply that the court "may take appropriate action." ME. R. CRIM. P. 16A(b).

${ }^{36}$ See ARIz. R. Crim. P. 15.7(b); ARK. R. CRIM. P. 19.7(a); ILL. SuP. CT. R. 415(g)(i); Iowa R. Crim. P. 10(11d); Minn. R. Crim. P. 9.03 (subd. 8); Miss. Uniform CIR. CT. R. 4.07; Mo. R. CRim. P. 25.16; N.J.R. CRIM. Prac. 3:11-2; N.Y. Crim. Proc. LaW § 250.20(3) (McKinney 1982); PA. R. CrIm. P. 305(C)(1)(d); R.I.R. CRIM. P. 16(i); Wash. R. CRIM. P. 4.7(h)(7). In Oklahoma, continuance is the sole sanction. OKLA. Stat. AnN. tit. 22, § 585 (West 1969).

${ }^{37}$ See ARIz. R. CRIM. P. 15.7(c); ARK. R. CRIM. P. 19.7(b); ILL. SUP. CT. R. 415(g)(ii). In Washington, a contempt sanction appears to be the sole judicially-approved response. State v. Nelson, 14 Wash. App. 658, 661, 545 P.2d 36, 38 (1975). See infra Appendix.

${ }^{38}$ See infra Appendix; cf. infra notes 136-39 and accompanying text (discussing use of 


\section{Challenges to the Constitutionality of Alibi Notice Rules and the Preclusion Sanction}

\section{A. The Constitutionality of Alibi Notice Rules Generally}

Alibi notice rules have consistently been upheld against constitutional attack. ${ }^{38}$ In Williams $v$. Florida, ${ }^{40}$ the Supreme Court held that Florida's pretrial alibi notice rule ${ }^{41}$ violated neither the defendant's fifth amendment privilege against self-incrimination ${ }^{42}$ nor his rights to due process or fundamental fairness. ${ }^{43}$ The Court rejected the due process argument summarily, since the notice rule applied to the prosecution as well as to the defendant." As to the fifth amendment claim, the Court reasoned that the rule simply required the defendant to make the same tactical choice he would otherwise make at trial, a choice between not introducing evidence at all and introducing it with the attendant danger of revealing the identity of witnesses and risking the emergence of damaging information; ${ }^{45}$ that choice had never been considered a violation of the privilege against self-incrimination. ${ }^{46}$

discretion by trial courts).

39 See Annot., 45 A.L.R.3D 958, 965-74, 47-49 Supp. (1972 \& Supp. 1983) (alibi notice rules upheld in state courts against attacks on several constitutional grounds). The precarious constitutional position of criminal discovery in general, see supra note 3 , is reflected in certain state statutes that explicitly make criminal discovery or alibi notice "subject to constitutional limitations." See, e.g., ARK. R. CRIM. P. 18.3; ILL. SUP. CT. R. 413(d); Mo. R. CRIM. P. 25.05; Wash. R. Crim. P. 4.7(b)(2).

to 399 U.S. 78 (1970).

41 Fla. R. Crim. P. 1.200 (1970) (current version at FlA. R. CRIM. P. 3.200), quoted in Williams, 399 U.S. at 104 app. Florida's rule is typical of a number of state rules in that it is prosecutor-triggered, specifically exempts the defendant's own testimony from exclusion, specifically states that witnesses whose names and address are not disclosed may be barred from testifying, provides for a continuing duty to disclose, imposes a reciprocal duty on the prosecutor, see supra note 8 and accompanying text, and allows waiver of the exclusion sanction for good cause shown. See infra Appendix.

12399 U.S. at 82-86.

1s Id. at 81-82; see also Annot., 45 A.L.R.3p 958, 967-68, 47-49 Supp. (1972 \& Supp. 1983) (citing state cases which have supported alibi notice statutes on due process or fundamental fairness grounds).

"Williams, 399 U.S. at 81.

15 Id. at 83-84.

16 Id. at 84. The Supreme Court has considered the validity of alibi notice rules in only one other case since Williams, Wardius v. Oregon, 412 U.S. 470 (1973). In that case, the Court found the Oregon alibi notice statute, OR. REv. STAT. $§ 135.875$ (currently renumbered as OR. REv. STAT. § 135.455 (1981)), quoted in Wardius, 412 U.S. at 472 n.3, to be unconstitutional due to its failure to provide reciprocal discovery rights to the defendant. The majority stated that "[i]t is fundamentally unfair to require a defendant to divulge the details of his own case while at the same time subjecting him to the hazard of surprise concerning refutation of the very pieces of evidence which he disclosed to the State." Wardius, 412 U.S. at 476 . 


\section{B. The Constitutionality of the Preclusion Sanction}

In contrast to the alibi notice rule, the preclusion sanction that enforces it in most jurisdictions has come under increasing attack in recent years as a violation of a defendant's right to present a defense. Commentators have asserted that the state's interest in encouraging truthful alibis and in the efficient administration of justice does not outweigh the constitutional right of the accused to defend himself. ${ }^{47}$ This section will survey the development of the constitutional attack on the preclusion sanction beginning with the sanction's early and longstanding acceptance, through the Supreme Court's recognition of the defendant's right to present a defense, and culminating in the Seventh Circuit's recent decision striking down the preclusion sanction in Alicea $v$. Gagnon..$^{48}$

1. The Traditional Analysis. State courts have unanimously rejected constitutional attacks on the preclusion sanction. ${ }^{49}$ In upholding the sanction over arguments that it violates the defendant's rights to call witnesses ${ }^{50}$ and to testify in his own behalf, state courts have primarily adopted a single mode of analysis. Most state courts have found that the rule does not prohibit alibi evidence absolutely, but rather places a reasonable procedural condition on the presentation of such evidence, ${ }^{52}$ a condition that the

${ }^{7}$ E.g., Clinton, The Right to Present a Defense: An Emergent Constitutional Guarantee in Criminal Trials, 9 IND. L. REv. 711, 830-41 (1976) (arguing for a test that balances the state's interest in efficient administration against the defendant's constitutional right and finding that the government's arguments are not sufficiently compelling to outweigh the defendant's constitutional right); Westen, The Compulsory Process Clause, 73 Mrch. L. REv. 71, 137-39 (1974) (discussing the alibi notice rule and arguing that the use of alternatives to the preclusion sanction in enforcing the notice rule is required in light of the history and recent understanding of the compulsory process clause); Note, supra note 11 (arguing that the "credibility of the evidence" justification for the preclusion sanction fails in the face of the construction given the compulsory process clause in Washington v. Texas, 388 U.S. 14 (1967), and that the preclusion sanction constitutes an unconstitutional condition infringing due process since less drastic means of protecting state interests are available).

${ }^{48} 675$ F.2d 913 (7th Cir. 1982).

4 See, e.g., State v. Roberts, 226 Kan. 740, 744, 602 P.2d 1355, 1358 (1979); State v. Smith, 88 N.M. 541, 543-44, 543 P.2d 834, 836-37 (Ct. App. 1975); Commonwealth v. Vecchiolli, 208 Pa. Super. 483, 489, 224 A.2d 96, 99 (1966); cf. State v. Dodd, 101 Ariz. 234, 237, 418 P.2d 574 (1966) (sanction upheld in face of attack based on state constitutional provisions identical to compulsory process clause of federal constitution).

so See, e.g., cases cited supra note 49.

${ }^{1}$ See, e.g, State ex rel. Simos v. Burke, 41 Wis. 2 d 129, 136-38, 163 N.W.2d 177, 180-81 (1968); see also State v. Wardius, 6 Or. App. 391, 397-98, 487 P.2d 1380, 1383-84 (1971) (right to testify based on state constitution), rev'd on other grounds, 412 U.S. 470 (1973).

${ }^{82}$ See cases cited supra note 49 . A few state court decisions endorse the preclusion sanction as a guarantor of the credibility of alibi evidence, reasoning that any undisclosed alibi evidence is likely to be untruthful. For example, in State ex rel. Simos v. Burke, 41 Wis. $2 \mathrm{~d} 129,163$ N.W.2d 177 (1968), the Wisconsin Supreme Court reasoned that a defen- 
preclusion sanction enforces. In State $v$. Smith, ${ }^{\text {ss }}$ for example, the New Mexico Court of Appeals compared alibi notice to conditioning the constitutional right to a jury trial on a defendant's timely request for a jury. ${ }^{54}$ In neither case, concluded the court, is the procedural condition antithetical to the constitutional right. ${ }^{55}$

Only one federal court had addressed the constitutionality of the preclusion sanction before the Seventh Circuit considered the issue in Alicea $v$. Gagnon. ${ }^{58}$ In Rider $v$. Crouse, ${ }^{57}$ the Tenth Circuit relied on a similar "reasonable condition" rationale to uphold the sanction. The habeas corpus petitioner in Rider argued that his constitutional right to testify about his alibi was improperly denied at his trial. ${ }^{58}$ The Tenth Circuit rejected that claim, reasoning:

The purpose of a statute like [the Kansas rule] concerning notice of alibi is to prevent a last minute surprise of an alibi defense. It does not deny an accused the right to such a defense but merely prescribes notice as a prerequisite thereto. The validity of such statutes is generally upheld. ${ }^{80}$

dant presenting a truthful alibi is not harmed by a pretrial notice requirement, seeming to assume that any alibi raised at trial without prior notice would be untruthful. Id. at 137, 163 N.W.2d at 180-81. An untruthful alibi, the court concluded, is not constitutionally protected; a defendant's constitutional right to testify extends only to the right to testify truthfully, just as other testimony is routinely excluded if immaterial or irrelevant. Id. at 137-38, 163 N.W.2d at 181; see also State v. Flohr, 301 N.W.2d 367, 372 (N.D. 1981) ("The rule . . . seeks . . . to insure . . . that presentation of evidence at trial will be fair and reliable."); State v. Wardius, 6 Or. App. 391, 397-98, 487 P.2d 1380, 1383-84 (1971), (quoting State ex rel. Simos v. Burke, 41 Wis. $2 \mathrm{~d}$ at 136-38, 163 N.W.2d at 180-81), rev'd on other grounds, 412 U.S. 470 (1973). Since the Supreme Court's decision in Washington v. Texas, 388 U.S. 14, 19-23 (1967), holding that any a priori state statutory categorization of evidence that arbitrarily excludes defense witnesses by presuming them to be unworthy of belief violates the defendant's compulsory process rights, see infra notes 60-67 and accompanying text, the "credibility of the evidence" rationale for the preclusion sanction has been discredited. See Note, supra note 11, at 1343-51. Cf. State v. Douglas, 292 Or. 516, 530-33, 641 P.2d 561, 57477 (1982) (Lent, J., specially concurring) (criticizing presumption of incompetence accepted in State v. Wardius, 6 Or. App. at 397-98, 487 P.2d at 1383-84); Note, supra note 11, at 1348-49 (arguing that the doctrine of presumptive untrustworthiness of alibi evidence weakens the adversarial process).

s3 88 N.M. 541, 543 P.2d 834 (Ct. App. 1975).

s4 Id. at 543-44, 543 P.2d at 836-37 (citing Carlile v. Continental Oil Co., 81 N.M. 484, 468 P.2d 885 (Ct. App. 1970), where the court held constitutional a statute conditioning a defendant's right to a jury trial upon a timely request).

ss Smith, 88 N.M. at 543-44, 543 P.2d at 836-37; see also State v. Mai, 294 Or. 269, 274, 656 P.2d 315, 319 (1982) (pretrial disclosure analogous to conditioning witnesses' appearance on issuance of subpoena and payment of witness fee).

68 675 F.2d 913 (7th Cir. 1982).

${ }^{87} 357$ F.2d 317 (10th Cir. 1966).

s8 Id. at 317 .

s9 Id. at 318 (citation omitted). General acceptance of the use of a preclusion sanction as a response to a failure to comply with procedural rules is evidenced by the adoption of 
2. Recognition by the Supreme Court of the Right to Present a Defense. In recent years, courts and commentators have begun to question the heretofore generally accepted constitutional justification for the preclusion sanction as a reasonable condition on the defendant's presentation of evidence. Those courts and commentators have premised their attacks on the existence of a constitutional right to present a defense. Beginning with Washing-

such sanctions in other areas of criminal procedure. Under the Federal Rules of Criminal Procedure, failure to notify the prosecution of an intention to rely on an insanity defense or of expert testimony related to the defense can result in the exclusion at trial of the defense or the testimony of any expert witness on the issue of the defendant's mental state. Fen. $R$. CRIM. P. 12.2. Federal courts have endorsed this sanction, although it has not been subject to constitutional challenge. Applications of the sanction have instead been challenged as abuses of discretion. United States v. Veatch, 647 F.2d 995, 1002-03 (9th Cir. 1981) (failure to give notice of defense based on mental condition constitutes a waiver of that defense), cert. denied, 456 U.S. 946 (1982); United States v. Olson, 576 F.2d 1267, 1273 (8th Cir.) (pro se defense does not excuse compliance with rule 12.2), cert. denied, 439 U.S. 896 (1978); United States v. Edwards, 90 F.R.D. 391, 397-98 (E.D. Va. 1981) (exclusion not an abuse of discretion because any other rule would promote the use of $12.2(\mathrm{~b})$ motions solely to gain continuances).

Criminal discovery orders under rule 16 of the Federal Rules of Criminal Procedure may be enforced by the exclusion of the evidence not disclosed. FED. R. CRIM. P. 16(d)(2). Rule 16 preclusion appears to be applied most commonly against the prosecutor. See United States v. Campagnuolo, 592 F.2d 852, 856-58 (5th Cir. 1979) (not an abuse of discretion for a trial court to prevent the prosecution from introducting a statement made by defendant in violation of standing district court order due to government's failure to inform defense counsel of the statement); United States v. Lewis, 511 F.2d 798, 801-03 (D.C. Cir. 1975) (lower court's inclusion at trial of an oral statement made by the defendant that the government did not disclose to the defendant's attorney held an abuse of discretion). The constitutionality of employing a preclusion sanction in response to a defendant's noncompliance is the subject of controversy. Compare United States v. Davis, 639 F.2d 239, 242-43 (5th Cir. 1981) (holding that sixth amendment right to compulsory process forbids exclusion of evidence solely as a sanction to enforce discovery rules against defendants) and AMERICAN BAR Association Standards for Criminal Justice § 11-4.7, at 11.67-68 (1980) ("The exclusion sanction is not recommended because its results are capricious . . . [and because] the exclusion of defense evidence raises significant constitutional issues." (footnote omitted)), with State v. Mai, 294 Or. 269, 276, 656 P.2d 315, 321 (1982) (holding that use of the preclusion sanction for violation of disclosure requirements under discovery rules does not violate the sixth amendment right of compulsory process when no effective alternative sanctions are available). In United States v. Davis, 639 F.2d 239 (5th Cir. 1981), decided a year before Alicea, the Fifth Circuit reversed a conviction in part on the ground that the exclusion of defense witnesses as a sanction for the violation of a pretrial discovery order violated the defendant's sixth amendment right to compulsory process. The Davis trial court had refused to admit testimony of defendant's character witnesses because their names had not been disclosed to the prosecutor before trial, in violation of a discovery order requiring such disclosure, and because their testimony would be needlessly cumulative. Id. at 242 . The Fifth Circuit held that the trial court not only abused its discretion in finding no probative value in the evidence, id. at 243-45, but was also unjustified in unilaterally revoking the right to present defense witnesses simply as a means to punish the failure to comply with the discovery order, id. at $242-43$. 
ton v. Texas, ${ }^{60}$ the Supreme Court has suggested that such a right may indeed by found in the fifth, ${ }^{61}$ sixth, ${ }^{62}$ and fourteenth ${ }^{63}$ amendments. The right is composed of at least two elements: the right to call witnesses and the right to testify in one's own defense. The defendant in Washington challenged a Texas statutory rule ${ }^{64}$ barring principals, accomplices, and accessories to the same crime from testifying for each other. The apparent justification for the rule was that accomplices, because of their inherent interest in the result, were not credible witnesses. ${ }^{85}$ The Court held that the compulsory process clause not only repudiates the ancient common law rule barring the defendant from calling witnesses in his favor, ${ }^{66}$ it also prohibits "arbitrary" disqualification of any category of witnesses presumed a priori to be untrustworthy. ${ }^{67}$ In 1973 the Supreme Court relied on the due process clause to strike down a Mississippi voucher rule that prevented a defendant from calling witnesses to impeach the damaging testimony of one of his own witnesses. ${ }^{68}$ Justice Powell, writing for the majority, reaffirmed the principle of compulsory process and construed it as a necessary element of due process, concluding that "the rights to confront and cross-examine witnesses and to call witnesses in one's own behalf have long been recognized as essential to due process."

The right of a defendant to testify in his own behalf has yet to receive such clear endorsement by the Supreme Court. At common

388 U.S. 14 (1967).

-2 U.S. CoNST. amend. V ("No person shall . . . be deprived of life, liberty, or property without due process of law ....").

a U.S. ConsT. amend. VI ("In all criminal prosecutions, the accused shall enjoy the right to . . . have compulsory process for obtaining witnesses in his favor . . . ."). In relying on the compulsory process clause in Washington, the court construed that clause for the first time in 120 years. See Westen, supra note 47, at 108-11 (discussing the prior Supreme Court rulings on the compulsory process clause).

s U.S. ConsT. amend. XIV, $\$ 1$ ("nor shall any State deprive any person of life, liberty, or property, without due process of law").

of Tex. Stat. ANN. art 82,711 (Vernon 1925), repealed by Acts of 1965, 59th Leg., ch. 722, at 317, amended by Acts of 1967, 60th Leg., ch. 659, $\S 21$, at 1739 (presently codified at Tkx. Code Crim. Proc. Ann. art. 36.09 (Vernon 1965)).

6 Washington, 388 U.S. at $20-21$.

so Id. at 19-20.

67 Id. at 23; see also Westen, supra note 47, at 111-17 (discussing the case). In the course of applying the compulsory process clause to the Texas statute at issue in Washington, the Court also held that that clause is incorporated into the due process clause of the fourteenth amendment and hence applies to the states. 388 U.S. at 17-19.

e* Chambers v. Mississippi, 410 U.S. 284 (1973). For a discussion of the Supreme Court's confused analysis in this case of the constitutional bases for a right to present a defense, see Clinton, supra note 47, at 783-93.

410 U.S. at 294. 
law a defendant had no right to testify in his own defense, ${ }^{70}$ nor does the Constitution explicitly provide such a right. Nevertheless, the federal government and all of the states have created such a right by statute. ${ }^{71}$ Moreover, the Supreme Court has, in dicta, implied support for the notion of the right to testify, not from the right to compulsory process, but as a fundamental element of due process. ${ }^{72}$ In Brooks $v$. Tennessee, ${ }^{73}$ the Court noted that "[w] sion as well as a matter of constitutional right." "74 In Faretta $v$. California ${ }^{75}$ the Court listed the right to testify as one of several constitutional rights "essential to due process of law in a fair adversary process," the thus effectively deeming it a fundamental

${ }^{70}$ Washington, 388 U.S. at 20; Hammerman, A Criminal Defendant's Constitutional Right to Testify-The Implications of United States ex rel. Wilcox v. Johnson, 23 Vicl. L. REv. 678, 680-82 (1977-78).

${ }^{71}$ See, e.g., Ferguson v. Georgia, 365 U.S. 570, 573-81 (1961) (discussing development of such competency statutes); 18 U.S.C. $\$ 3481$ (1982) ("In trial of all persons charged with the commission of offenses against the United States . . . the person charged shall, at his own request, be a competent witness."); Wrs. R. Evid. 906.01 (West 1982) ("Every person is competent to be a witness . . . ." "); Ferguson v. Georgia, 365 U.S. 570, 573-81 (1961) (discussing development of such competency statutes). See also Hammerman, supra note 70, at 682 (discussing the differences between statutory and constitutional guarantees of the right to testify in one's own behalf, and concluding that the constitutional guarantee is preferable in that it guarantees a higher standard for waiver of the right); Note, Due Process v. Defense Counsel's Unilateral Waiver of the Defendant's Right to Testify, 3 Hastings Const. L.Q. 517, 541-42 (1976) (listing state statues making criminal defendants competent witnesses).

${ }^{22}$ See, e.g., In re Oliver, 333 U.S. 257, 273 (1948) ("A person's right to . . . an opportunity to be heard in his defense . . . [is] basic in our system of jurisprudence; and [his] right[] include[s], as a minimum, a right ... to offer testimony ...."). See generally, Clinton, supra note 47 , at 756-93. The right to testify can be seen as part of the right to present a defense. See United States v. Bentvena, 319 F.2d 916, 943 (2d Cir.), cert. denied, 375 U.S. 940 (1963).

Clinton notes that the "right" to present a defense has been derived from different constitutional sources in different cases. Clinton, supra note 47 , at 792-93. See, e.g., Chambers v. Mississippi, 410 U.S. 284, 294-303 (1973) (due process and confrontation clauses); Cool v. United States, 409 U.S. 100, 104 (1972) (compulsory process clause); Webb v. Texas, 409 U.S. 95, 98 (1972) (fourteenth amendment due process clause); Brooks v. Tennessee, 406 U.S. 605, 607-13 (1972) (privilege against self-incrimination and right to counsel); Washington v. Texas, 388 U.S. 14, 17-18 (1967) (compulsory process clause); In re Oliver, 333 U.S. 257, 273 (1948) (due process clauses).

73406 U.S. 605 (1972).

7t Id. at 612. In Brooks, the Supreme Court held that a Tennessee statute requiring that a defendant in a criminal proceeding who "desir[es] to testify . . . do so before any other testimony for the defense is heard by the court trying the case" violates the defendant's privileges against self-incrimination. Id. at 612 (citing TENN. CoDE ANN. § 40-2403 (1955)). The Court held that the defendant should not be penalized for remaining silent at the close of the state's case by being excluded from taking the stand later in the trial. Id. at 610 .

${ }^{75} 422$ U.S. 806 (1975).

${ }^{78}$ Id. at 819 n.15. 
right. ${ }^{77} \mathrm{~A}$ number of lower federal and state courts have explicitly found a constitutional right to testify in one's own behalf. ${ }^{78}$

3. Alicea: Balancing the State's Interests Against the Defendant's Rights. In Alicea v. Gagnon, ${ }^{79}$ the Seventh Circuit struck down Wisconsin's alibi notice rule as a violation of what it held to be a defendant's constitutional right to testify on his own behalf. In Alicea, the defendant was tried for armed and masked robbery in a Wisconsin state court. ${ }^{80}$ At trial Alicea sought to testify that he was at home on the morning of the robbery. ${ }^{81}$ Because he had failed to provide advance notice of the alibi, the court prevented him from so testifying. ${ }^{82}$ Although Alicea was able to testify that

27 See also Harris v. New York, 401 U.S 222, 225 (1971); In re Oliver, 333 U.S. 257, 273 (1948).

78 See, e.g., Winters v. Cook, 489 F.2d 174, 179 (5th Cir. 1973) (dicta); United States v. McCord, 420 F.2d 255, 257 (D.C. Cir. 1969); United States v. Bentvena, 319 F.2d 916, 943-44 (2d Cir.), cert. denied, 375 U.S. 940 (1963); Poe v. United States, 233 F. Supp. 173, 176 (D.D.C. 1964), aff'd, 352 F.2d 639 (D.C. Cir. 1965). The Ninth Circuit has discussed the constitutionality of the right to testify in a series of cases without reaching a definite holding with regard to the source of the right. See, e.g., United States v. Panza, 612 F.2d 432, 438 (9th Cir.) (noting that the right is qualified), cert. denied, 447 U.S. 925 (1980); United States v. Hearst, 563 F.2d 1331, 1340 (9th Cir. 1977) (cross-examination limits the right); United States v. Ives, 504 F.2d 935, $941-42$ (9th Cir. 1974) (a defendant may expressly or impliedly waive the right). Most state cases rely on statutory grounds for the right to testify in one's own behalf. See supra note 71; see also Smetana v. Smith, 22 Ohio L. Abs. 165, 166 (Ct. App.), appeal dismissed, 131 Ohio St. 329, 2 N.E.2d 778 (1936).

79675 F.2d 913 (7th Cir. 1982).

${ }^{80} \mathrm{Id}$. at 914.

81 Id. at 915 .

s2 Id. The Wisconsin statute does not provide specific protection for the defendant's right to testify. Twenty-four out of the 41 states that have alibi notice rules do specifically reserve to the defendant the right to testify regarding his alibi. See infra Appendix. The court specifically refrained from addressing this difference in Wisconsin's alibi notice rules from the alibi notice rules of other states. Alicea, $675 \mathrm{~F} .2 \mathrm{~d}$ at 917 n.6. The decision, therefore, has little direct precedential value for those states whose preclusion sanction applies only to witnesses called by the defendant. Presumably, however, under the Alicea balance test, the defendant's constitutional right to compulsory process to obtain the testimany of witnesses would outweigh the state's interest in efficiency, just as the defendant's right to testify in his own behalf outweighs the state's interest in efficiency, because the cost to the defendant in terms of potential lost liberty is greater than the administrative benefits to the state. On the other hand, the Alicea court seemed to suggest that the defendant's own right to testify might be stronger than his right to call other witnesses because it is the defendant's own freedom which "hangs in the balance" of the trial. Id. at 923. The Supreme Court's reasoning in Faretta v. California, 422 U.S. 806 (1975), upholding a defendant's right to reject court-appointed counsel and conduct his own defense, also suggests that the participation of the defendant in the proceedings must be accorded a special weight when the defendant wishes to participate. Id. at 812-34. Because the right to call witnesses, or "compulsory process," however, is grounded directly in the language of the sixth amendment and more strongly supported by history, the Alicea balance would likely be struck at least as deferentially toward the defendant's right to call witnesses as it was in Alicea itself toward his right to testify. 
he had not left home at the time the crime occurred and to deny committing the robbery, the jury did not receive instructions concerning an alibi defense and Alicea was convicted..$^{83}$

In his habeas corpus petition to the Seventh Circuit, Alicea challenged the constitutionality of the preclusion sanction. ${ }^{84}$ Establishing a defendant's constitutional right to testify on his own behalf was crucial to Alicea's case since state habeas corpus petitioners may obtain review in federal court only if they allege the deprivation of a constitutional right. ${ }^{85}$ After thorough analysis and review of the precedents, ${ }^{88}$ the court concluded that the fifth, sixth, and fourteenth amendments supported a constitutional right to testify in one's own behalf. ${ }^{87}$ The court reasoned: "If the search for truth is to have meaning, surely the most important figure in the controversy, whose very freedom hangs in the balance, must have a right to participate directly." 88

Having established the constitutional right, the court then weighed the state's interest supporting the preclusion sanction against the sanction's effect on the right. ${ }^{80}$ The court emphasized that in balancing federal constitutional rights and state procedural rules, "the competing state interests must be substantial to overcome the claims of the defendant." ${ }^{\prime 90}$ Wisconsin asserted interests

ss 675 F.2d at 915 .

84 Id. at 916.

${ }^{83} I d$. at 920.28 U.S.C. $\$ 2241$ (c)(3) (1976) provides the habeas remedy for persons in custody "in violation of the Constitution or laws or treaties of the United States." Precedents suggest that the error must be of federal constitutional dimension. See, e.g., Fay v. Noia, 372 U.S. 391 (1963) (coerced confession in violation of fifth amendment); Brown v. Allen, 344 U.S. 443 (1953) (coerced confession in violation of the fifth amendment); Johnson v. Zerbst, 304 U.S. 458 (1938) (lack of counsel at trial in violation of sixth amendment). 28 U.S.C. \$ 2254 (d) (1976) provides the conditions of review to be met by a state prisoner seeking habeas review in federal court. 28 U.S.C. $\S 2255$ (1976) provides different conditions for a federal prisoner seeking comparable post-conviction review in federal court. The constitutional dimensions of a right also have an impact on areas other than habeas corpus petitions. For example, courts are more likely to impose a lower standard for an effective waiver of a right that is merely statutory, rather than constitutional. See Hammerman, supra note 70 , at 684-86.

${ }^{88}$ In reaching its holding, the Seventh Circuit "partially overruled" an earlier Seventh Circuit case, Sims v. Lane, 411 F.2d 661, 664 (7th Cir.), cert. denied, 396 U.S. 943 (1969), which held that the privilege of the accused to testify is "merely statutory." Alicea, 675 F.2d at 923. The court reasoned that Sims was "obsolete" because it had been decided before the Supreme Court's persuasive dicta in Brooks and Faretta. Id. at 921-22; see supra notes 7377 and accompanying text (discussing Brooks and Faretta).

${ }^{87}$ Alicea, 675 F.2d at 922-23.

88 Id. at 923.

s9 Id. at $923-25$.

${ }^{90}$ Id. at 923 (quoting McMorris v. Israel, $643 \mathrm{~F} .2 \mathrm{~d} 458,460-61$ (7th Cir. 1981), cert. denied, 455 U.S. 967 (1982)). 
in preventing false alibis and in facilitating the efficient administration of justice. The court held these interests insufficient to defeat the defendant's right to testify, finding that the state, with its superior investigatory power, would rarely be surprised by the presentation of truthful alibi, ${ }^{91}$ and that an unsubstantiated alibi, such as the one Alicea attempted to introduce by his testimony alone, could hardly hinder the state's prosecutorial efforts given the prosecution's opportunity to cross-examine or impeach the defendant at trial..$^{22}$ The court noted that the state could always seek a continuance for further investigation if the surprise alibi seriously prejudiced its case. ${ }^{93}$ Having thus found that the state's interest in precluding the testimony was unsubstantial, and that any damage to the prosecution through undisclosed testimony was probably de minimis, ${ }^{94}$ the court held that the defendant's alibi testimony could not be precluded. ${ }^{25}$

\section{The Preclusion Sanction and Procedural Default}

Alicea balances the value to the state of alibi notice against the cost to the defendant of losing his right to testify or to present witnesses to establish an alibi defense. Because the Alicea court found very few real benefits to the state from the rule, it reasoned that the cost to the defendant of excluding his testimony outweighed these slight benefits. ${ }^{96}$ Yet this analysis seriously misconstrues the cost an alibi notice rule imposes on the defendant. If the defendant complies with the notice rule, he loses only the ability to

91 Id. at 924. The court also noted that "[a]s an essential part of its case, the state must prove a defendant's presence during the commission of an alleged crime, proof which invariably requires pretrial investigation and preparation. Armed with this evidence, the state is in a formidable position to refute a defendant's unexpected alibi testimony . . . ." Id. The court did not, however, address the possibility of a defendant being able to raise a reasonable doubt through such unexpected testimony, see supra note 2 , a possibility that might be reduced if the prosecutor has sufficient warning of the details of the alibi testimony.

22 Alicea, 675 F.2d at 924 .

os Id.

24 While a response to the Seventh Circuit's analysis is presented infra notes 96-131 and accompanying text, it should be noted here that the Alicea court's finding that the state interest served by an alibi notice rule is minimal is directly contrary to the Supreme Court's finding in Williams v. Floride, 399 U.S. 78, 81-82 (1970), that such rules further the search for truth in criminal trials and the efficient administration of justice.

9s Alicea, 675 F.2d at 925-26. Nonetheless, even though Alicea's constitutional right to testify had been violated, the court noted that the evidence against him was overwhelming. Moreover, Alicea had been able to introduce certain alibi testimony despite the preclusive ruling. For these reasons, the court found that the deprivation constituted harmless error and affirmed the conviction. Id.

96 Alicea, 675 F.2d at 924 . 
keep his intention of presenting an alibi defense secret until the trial itself. It is solely as the result of his failure to comply with rule that he forfeits his right to present alibi evidence. This Part will show that the balancing test adopted by the Seventh Circuit in Alicea, ${ }^{97}$ if carried to its logical conclusion, would condemn as violative of defendants' constitutional rights not only use of the preclusion sanction for violations of the alibi notice rule, but also a host of other well-accepted principles of criminal procedure.

\section{A. Procedural Default and Balancing in Other Contexts}

To evaluate the Alicea test it is first necessary to recognize the aspects of procedural default present in alibi notice rules. Procedural default has been defined as the loss of a right through a failure by an accused or his representative to assert that right in a prescribed manner or at a required time. ${ }^{88}$ By creating an alibi notice rule, the state dictates when an intention to offer alibi evidence may be announced; $;^{\theta \theta}$ a defendant's failure to provide notice at that time operates as a forfeiture of the right to present alibi testimony, including, in some states, the defendant's own testimony, at trial. The forfeiture operates automatically; no state official will ask the defendant why he has not given notice.

A number of considerations justify the deprivation of a constitutional right by procedural default. A defendant and his counsel necessarily make many tactical decisions in the course of a prosecution, including decisions not to assert certain constitutional rights. It would be far too time-consuming and inefficient to require judges to inquire specifically into a defendant's understanding of and concurrence in all of those decisions. ${ }^{100}$ At the same

97 The Alicea balancing test seems first to have been proposed by the author of a 1972 student note. See Note, supra note 11 . This analysis can be applied to any procedural rule that denies the defendant the ability to exercise a constitutional right based on an earlier failure to assert the right. See infra note 100.

${ }^{98}$ Spritzer, Criminal Waiver, Procedural Default and the Burger Court, 126 U. PENN. L. REv. 473, 474-77, 513-14 (1978).

99 Williams v. Florida, 399 U.S. 78, 85 (1970).

${ }^{100}$ See Spritzer, supra note 98, at 476-77. Procedural default should be distinguished from waiver, the other principal means by which a defendant is deemed to have foregone a constitutional right. Johnson v. Zerbst, 304 U.S. 458 (1938), provides the classic definition of waiver as "an intentional relinquishment or abandonment of a known right or privilege." Id. at 464 . Waiver requires an affirmative showing on the record that the defendant knowingly and voluntarily acquiesced in foregoing the right. See Spritzer, supra note 98 , at 475 . The Supreme Court has required an affirmative waiver in a number of contexts, for example, the right to counsel, see, e.g., Johnson v. Zerbst, 304 U.S. 458, 464 (1938), the fifth amendment privilege against self-incrimination, see, e.g., Miranda v. Arizona, 384 U.S. 436, 475 (1966), and the surrender of trial rights by a guilty plea, see, e.g., Boykin v. Alabama, 395 U.S. 238, 
time procedures exist for the defendant to assert certain rights at relatively less cost. Therefore, procedural default furthers efficiency and finality at trial.

The concept of procedural default is integral to at least two other familiar aspects of criminal procedure: contemporaneous-objection rules and the rules governing application for a new trial based on newly-discovered evidence. A defendant is required, under a contemporaneous-objection rule, to object to the introduction of inadmissible evidence by the prosecutor or to the use of improper jury instructions at the time the error is made; if he fails to object at that time he forfeits the right to object later in the trial or on appeal. ${ }^{101}$

A defendant may also lose the opportunity to submit evidence

242 (1969).

The distinction between waiver and procedural default has often been blurred in practice. Some commentators have used the word "waiver" to include both waiver as defined in Zerbst and procedural default. See, e.g., Rubin, Toward a General Theory of Waiver, 28 UCLA L. REv. 478, 483-86 (1981); see also Westen, Away from Waiver: A Rationale for the Forfeiture of Constitutional Rights in Criminal Procedure, 75 MrcH. L. RzV. 1214, 1214-15 (1977) (discussing the distinction between waiver and forfeiture of constitutional rights). The term waiver has also been employed to describe the loss of a right through inaction under a default standard. See Dix, Waiver in Criminal Procedure: A Brief for More Careful Analysis, 55 TEx. L. REv. 193, 194-204 (1977). For example, Rule 12 of the Federal Rules of Criminal Procedure creates a procedural default standard for the assertion of several defenses, objections, and requests that are "capable of determination without the trial of the general issue." FED. R. CRIM. P. 12(b). These include defenses and objections based on defects in the institution of the prosecution or in the indictment or information, motions to suppress evidence, requests for discovery under FED. R. CRIM. P. 16, and requests for a severance of charges or defenses under FED. R. CRIM. P. 14. The reasons for the procedural default standard of Rule 12 are typical, and include preventing unnecessary trials, deterring interruption of a trial for any objection relating to the institution and presentation of the charge, and eliminating from trial disputes over police conduct not immediately relevant to the question of guilt. See Sewell v. United States, 406 F.2d 1289, 1292 (8th Cir. 1969); FkD. R. Crim. P. 12 advisory committee note on 1974 Amendment; see also Davis v. United States, 411 U.S. 233 (1973) (approving preclusion sanction of Rule 12), discussed infra note 116. The rule provides that a failure to raise these defenses, objections, and requests in a timely manner "shall constitute waiver thereof, but the court for cause shown may grant relief from the waiver." FED. R. CRM. P. 12(f). The rule misapplies waiver terminology; forfeiture of a right without a formal review of the defendant's voluntariness and awareness constitutes procedural default.

${ }^{201}$ See, e.g., FED. R. CRIM. P. 30 ("No party may assign as error any portion of the charge or omission therefrom unless he objects thereto before the jury retires to consider its verdict, stating distinctly the matter to which he objects and the grounds of his objection."); see also Engle v. Isaac, 456 U.S. 107, 124 (1982) (A failure to object contemporaneously to improper jury instructions causes forfeiture of the objection under Ohio law; defendant must demonstrate "cause" for the default to raise the objection under federal habeas corpus.); Wainwright v. Sykes, 433 U.S. 72, 87-90 (1977) (same for failure to object in a timely fashion to the use of an improperly obtained confession); Henry v. Mississippi, 379 U.S. 443, 448-53 (1965) (same for failure to object to illegally obtained evidence). 
to the fact-finder if he fails to do so at his first trial. Federal Rule of Criminal Procedure 33 permits a new trial, at the request of the defendant, if newly discovered evidence becomes available. ${ }^{102}$ Even after the enactment of the rule, however, courts have continued to place strict limits on the right to a new trial, applying the test developed in Berry $v$. State. ${ }^{103}$ Berry prohibits new trials unless the evidence was discovered after the time of the first trial, could not with "due diligence" have been discovered earlier, is not merely cumulative or impeaching, and is of such a nature that it will likely produce an acquittal on retrial. ${ }^{104}$ The second listed factor is the most important for present purposes: if the defendant fails to use his best efforts to present his case at the first trial, he forfeits his right to present a complete defense. ${ }^{105}$ The similarities among the alibi notice, contemporaneous-objection, and new-trial rules are clear: in each case the state requires the defendant to assert certain of his substantive rights in a manner designed to serve the efficient, orderly, and fair operation of the criminal justice system. A failure to comply with the rule may cause a forfeiture of the right. $^{108}$ These similarities strongly suggest that an application of the Alicea test would render the contemporaneous-objection and

102 The court on motion of a defendant may grant a new trial to him if required in the interest of justice. If trial was by the court without a jury the court on motion of a defendant for a new trial may vacate the judgment if entered, take additional testimony and direct the entry of a new judgment. A motion for a new trial based on the ground of newly discovered evidence may be made only before or within two years after final judgment, but if an appeal is pending the court may grant the motion only on remand of the case. A motion for a new trial based on any other grounds shall be made within 7 days after verdict or finding of guilty or within such further time as the court may fix during the 7-day period.

FED. R. CRIM. P. 33.

${ }^{103} 10 \mathrm{Ga} .511,527$ (1851). For recent cases employing the Berry approach, see, for example, United States v. Wright, 625 F.2d 1017, 1019-20 (1st Cir. 1980); United States v. Pappas, 602 F.2d 131, 133 (7th Cir.), cert. denied, 444 U.S. 949 (1979); United States v. Allen, 554 F.2d 398, 403 (10th Cir.), cert. denied, 434 U.S. 836 (1977). The Berry case actually stated a six-part test that included the providing of an affidavit from the new witness himself, and some courts today use a five-part test, see, e.g., United States v. Herman, 614 F.2d 369, 371 (3d Cir. 1980), but there is no significant difference in the substance of any of the standards. $3 \mathrm{C}$. Wright, Federal. Practice and Procedure $\S 557$ (1982).

104 Berry v. State, $10 \mathrm{Ga} .511,527$ (1851).

103 See, e.g., United States v. Hedman, 655 F.2d 813, 815 (7th Cir. 1981); United States v. Rocco, 587 F.2d 144, 146-48 (3rd Cir. 1978), cert. denied, 440 U.S. 972 (1979); see also United States v. Massey, 629 F.2d 1084, 1086 (5th Cir. 1980) (court gave equal weight to three factors: evidence appears to be merely cumulative, is unlikely to change outcome at trial and was easily discoverable with due diligence before trial), cert. denied, 450 U.S. 969 (1981).

${ }^{108}$ In alibi notice cases, certain mitigating factors, such as those outlined infra notes 136-40 and accompanying text, may establish good cause and prompt a judge in his discretion to refuse to enforce the forfeiture. 
Berry rules unconstitutional.

Under the Alicea test, the value of contemporaneous-objection rules to the state would be weighed against the cost to the defendant, not of compliance with the rule, but of the procedural default resulting from non-compliance. ${ }^{107}$ Contemporaneous objection permits resolution of issues while the circumstances are fresh in the minds of the parties and encourages correction by the trial judge of errors without time-consuming appeals and retrials. ${ }^{108} \mathrm{~A}$ defendant who neglects to raise an objection at the proper time, however, may be wrongly convicted on the basis of prejudicial or unreliable evidence or as a result of improper jury instructions. Weighing these costs and benefits to a particular party at the time of appeal, as the Alicea court did, would likely result in the conclusion that the costs of forfeiture-wrongful conviction-outweigh the value to the state of the rule itself.

The Berry limitation on new trials serves similar state purposes: it promotes the efficient use of the judicial system's resources by forcing defendants to come forward with their claims and evidence as early as possible. As a result of that rule, however, a defendant who, through lack of diligence, fails to find exculpatory evidence in time for use at his first trial may be unable ever to present that evidence to a factfinder. Under Alicea, that result denies the accused his right to present a defense. Once again, balancing the state interest served against the loss of that right would suggest that the Berry rule is insupportable.

\section{B. The Benefits to the State Versus the Defendant's Cost of Compliance}

The flaw in the Alicea reasoning is its implicit assumption that the benefit to the state of the preclusion sanction must be weighed against the value of the defendant's constitutional right to present a defense. ${ }^{109}$ In fact, the burden imposed by the alibi no-

${ }^{107}$ See supra text accompanying notes 89-95.

108 Spritzer, supra note 98 , at 477.

109 Professor Clinton balances the same factors, value to the state versus the loss of defendant's right, to determine whether various procedural and evidentiary rules (including the alibi notice rule) violate the right to present a defense. Clinton, supra note 47 , at 797 . While the application of that test to alibi notice rules is improper for the reasons offered here, such a standard should be used to judge rules that automatically infringe the defendant's right. Clinton properly employed this balancing test to analyze Washington v. Texas, 388 U.S. 14 (1967), for example. Clinton, supra note 47, at 806-10. In that case the accomplice was precluded from testifying at the defendant's trial by the automatic operation of the evidentiary rule; no effort by the defendant at any time would have permitted him to 
tice rule as enforced by the preclusion sanction is merely the conditioning of that right on compliance with a particular procedure, not the loss of the right itself. Therefore, the test of the preclusion sanction's constitutionality is properly stated as a balance between the value to the state of the notice rule and the cost to the defendant of complying with the rule.

The constitutionality of the preclusion sanction may be assessed by comparing its balance of costs to the defendant and benefits to the state to the similar balancing required in other procedural-default contexts. For example, it is virtually costless for a defendant to object contemporaneously to errors at trial and thereby to assert the right to have such errors corrected, while the benefits to the state are great. ${ }^{110}$ The balance, therefore, tips heavily in favor of preserving the contemporaneous-objection rule and the benefits it provides to the state. Similarly, the Berry rule demands an exercise of "due diligence" in gathering evidence for trial. A defendant who offers at trial evidence resulting from that diligent effort effectively asserts his right to present his case before a fact-finder. Any exculpatory evidence that could not have been found with due diligence may then be offered at a new trial.111 The cost of acting with "due diligence" can hardly be burdensome to a defendant who has already accepted the cost of preparing a defense, and it therefore is outweighed by the savings of the state in avoiding multiple trials of the same matter.

In the case of alibi notice rules, the costs of compliance are those involved in preparing an alibi defense before trial and in responding to the prosecutor's request for such information. None of the costs of compliance are severe enough to constitute a deprivation of a constitutional right. ${ }^{112}$ The defendant has not failed to comply with the rule if his information is not complete at the time

overcome the prohibition and redeem his right to compulsory process. For that reason the existence of the rule necessarily led to a denial of the right, and the balancing of the state's interest against the value of the right itself was appropriate.

Professor Westen has employed a balancing of the same factors in assessing the constitutionality of conditioning one right on the waiver of another. See Westen, Incredible Dilemmas: Conditioning One Constitutional Right on the Forfeiture of Another, 66 Iowa L. REv. 741, 757-58 (1981) (when the assertion of one constitutional right is conditioned on the forfeiture of another, a court determining the validity of the condition should assess, for each right involved, the value to the state of compelling the choice against the defendant's interest in either right).

110 See generally 2 C. Wright, Federal Practice and Procedure: Criminal 2d § 484, at $698-99$ (1982).

11 See generally 3 id. \$ 557, at 315-40.

312 By giving pretrial notice the defendant does not lose his privilege against self-incrimination. Williams v. Florida, 399 U.S. 78, 84 (1970). 
of the request; the continuing duty to disclose imposed by rules such as Federal Rule of Criminal Procedure 12.1(c) ${ }^{113}$ requires the release of such information only as it is gathered, whether before or during trial. By contrast, although the Alicea court gainsaid the benefits of the alibi notice rule, ${ }^{114}$ other courts and commentators have noted the increase in administrative efficiency in the trial process when such a rule is in place. ${ }^{116}$ The costs, therefore, of asserting an alibi defense are as greatly outweighed by the benefits gained through avoidance of surprise alibis and the delays they can cause as the costs of the contemporaneous-objection and Berry rules are outweighed by their benefits. In sum, treating the preclusion sanction as the result of the defendant's own forfeiture of the right to present alibi witnesses preserves the benefits alibi notice rules provide to the state without jeopardizing the defendant's compulsory-process rights, ${ }^{116}$ and hence, by comparison with the balance of costs and benefits struck with respect to other procedural default rules, should be upheld.

Finally, preclusion is the least severe effective means of securing the benefits of an alibi notice rule to the state. Commentators

113 See supra note 24.

114 Alicea, 675 F.2d at 924; see supra text accompanying note 96.

110 See, e.g., Williams v. Florida, 399 U.S. 78, 81-82 (1970); State ex rel. Simos v. Burke, 41 Wis. 2d 129, 136, 163 N.W.2d 177, 180 (1968); Epstein, supra note 2, at 31-32; Flatten \& Watkins, supra note 2 , at $13-16$.

118 Also analogous to the alibi notice rule preclusion sanction is forfeiture of certain defenses and objections under Federal Rule of Criminal Procedure 12. The details of the defenses and objections included in that rule are discussed in the cases cited supra note 100. If the defendant fails to raise any of these matters before trial, he loses the opportunity to raise them. FED. R. CRIM. P. 12(f). The benefits to the criminal justice system from requiring disposition of these matters before trial include preventing unnecessary trials, deterring interruption of trials for any objection relating to the institution and presentation of the charge, and eliminating from trial disputes over police conduct not immediately relevant to the question of guilt. See supra note 100 . If the defendant fails to raise these matters before trial, the forfeiture mechanism may cause him to lose, inter alia, his right to a legally selected, unbiased grand jury, his right to discovery, and his right to avoid the introduction of illegally obtained evidence. Once again, under the Alicea test, the loss of these trial rights outweighs the gain to the system from streamlined trials.

Employing the test this comment suggests dictates the opposite result. Consistent with the analysis presented here, the Supreme Court has approved the Rule 12 preclusion sanction. Davis v. United States, 411 U.S. 233 (1973). Justice Rehnquist advanced two arguments in support of the sanction. First, the sanction was firmly rooted in precedent: the requirement that objections to the composition of a grand jury be raised before trial had been approved by the Supreme Court in 1883. Id. at 237 (citing United States v. Gale, 109 U.S. 65 (1883)). Second, the value to the criminal justice system of enforcing the rule outweighs the tactical value to the defendant of evading the rule's pretrial notice requirement and of raising various objections at trial, on appeal, or on collateral attack. Id. at 241. Thus the Court apparently balanced procedural costs and benefits, not procedural benefits versus the rights forfeited. 
criticizing the preclusion sanction have proposed a number of alternatives. ${ }^{117}$ These include granting a continuance when a surprise alibi arises at trial, ${ }^{118}$ prohibiting further pretrial discovery by the defendant, ${ }^{119}$ permitting the court or prosecutor to comment on the credibility of alibi evidence presented without prior notice, ${ }^{120}$ imposing criminal sanctions for a willful failure to comply with the notice rule, ${ }^{121}$ and imposing contempt sanctions against the defendant's attorney for a failure to comply. ${ }^{122}$ Proponents of these alternatives claim that each provides a constitutionally acceptable means of enforcing alibi notice, and therefore that preclusion is unnecessary as well as unconstitutional. ${ }^{123}$

None of these proposed sanctions actually provides an effective alternative to preclusion. Permitting a continuance for further investigation as the sole sanction is equivalent to abolishing alibi notice altogether. ${ }^{124}$ Even without an alibi notice rule, a continuance is available to the prosecution when unexpected evidence surfaces at trial. ${ }^{125}$ The threat of a continuance provides no real incentive to the defendant to conform to the rule, and it may even prove to be attractive as part of a tactical strategy designed to stall the trial. ${ }^{126}$ Prohibiting further pretrial discovery for a defendant who fails to give alibi notice is also the equivalent of no sanction at all; the threat of the preclusion sanction does not arise until mid-trial, well after the opportunity to discontinue discovery is lost. Permitting comment to the jury on the validity of a surprise alibi is of doubtful constitutionality. ${ }^{127}$ Criminal sanctions for a willful fail-

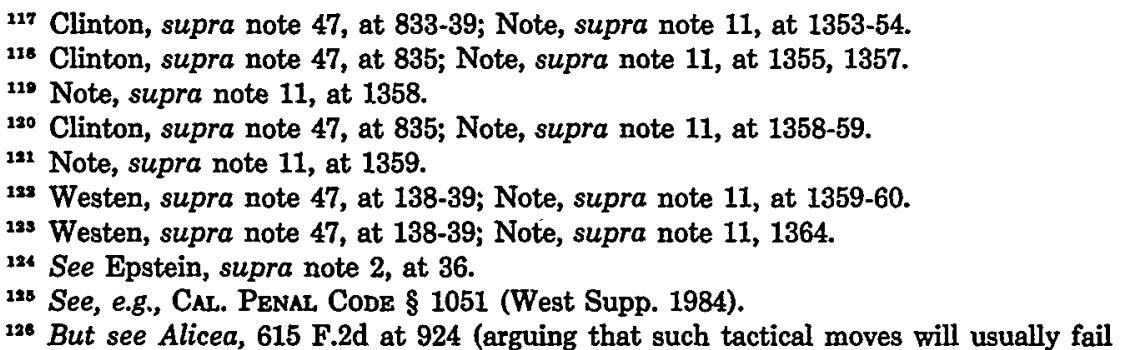
because there will be little surprise and hence no need for a continuance).

${ }^{127}$ First, such comment may serve to introduce, in a novel fashion, the $a$ priori presumption of untrustworthiness disallowed in Washington v. Texas, 388 U.S. 14, 22 (1967). See supra notes 52, 60-68 and accompanying text. Second, comment on a surprise alibi may violate due process by diminishing the prosecutor's burden of proving guilt beyond a reasonable doubt. As the Court noted in Cool v. United States, 409 U.S. 100 (1972), "[b]y creating an artificial barrier to the consideration of relevant defense testimony putatively credible by a preponderance of the evidence, the trial judge reduced the level of proof necessary for the Government to carry its burden." Id. at 104. Finally, this alternative sanction may be analogized to the violation of the privilege against self-incrimination caused by comment on defendant's own failure to take the stand. See Griffin v. California, 380 U.S. 609, 614 (1965). 
ure to comply with a notice rule would likely provide little incentive to the defendant who already faces considerable punishment for the principal crime and who believes a surprise alibi provides a tactical advantage. ${ }^{128}$ Finally, contempt sanctions against the lawyer would be at best ineffective, as experience with the Federal Rule of Civil Procedure $11^{129}$ sanction shows. ${ }^{130}$ At worst, contempt sanctions would create a conflict of interest between the defendant's desire to withhold alibi evidence as long as possible and the attorney's desire to avoid the sanction. This conflict would give the defendant an inducement to delay informing his attorney of alibi evidence in order to avoid having his attorney disclose the evidence rather than risk contempt. This inhibition impinges on the defendant's interest in the free flow of information to his attorney. ${ }^{131}$

\section{RECOMMENDATIONS}

In framing alibi notice rules, the goal of a state should be to minimize the costs of compliance while preserving the societal benefits the rule provides. As we have seen, the preclusion sanction is both constitutional and the least drastic effective means of preserving those benefits. Yet the burden the notice rule imposes on the defendant may be still further reduced by the adoption of a version of the rule which includes three elements: prosecutorial initiation, imposition of a flexible duty of disclosure, and judicial discretion.

\section{A. Prosecutor-Triggered Rule}

Federal Rule 12.1, like the rules in twenty-four states and the District of Columbia, ${ }^{132}$ requires the prosecutor to inform a defendant of his duty to provide pre-trial notice of an alibi defense. By triggering the process, the prosecutor ensures that the defendant's duty to provide notice, should he wish to present an alibi defense, is predicated on an awareness of the rule, thereby lowering the cost of compliance to the defendant. At the same time, since providing

${ }^{228}$ The student note recommending this alternative recognized this drawback. Note, supra note 11 , at 1359 .

220 Fen. R. Crv. P. 11 (requiring counsel to sign his pleading and attest that "he has read the pleading . . . [and] . . . it is well grounded in fact and is warranted by an existing law or a good faith argument for the extension . . . of existing law.")

130 2 Moore's Federar Practice at 6 (special alert supp. 1984).

131 See generally Freedman, Professional Responsibility of the Criminal Defense Lawyer: The Three Hardest Questions, 64 MrcH. L. Rkv. 1469, 1470-74 (1966) (discussing importance of confidentiality between attorney and client).

${ }^{132}$ See supra note 29 and accompanying text. 
notice of the rule is a routine procedure, it does not impose an undue burden on the prosecutor. ${ }^{133}$ As a state's goal should be to decrease the defendant's cost of compliance with the rule without diminishing the rule's value to the criminal justice system, it is entirely appropriate for states to adopt a prosecutor-triggered rule.

\section{B. Flexible Duty to Disclose}

Permitting the accused to release alibi information as he receives it, rather than only on a set day before trial, ${ }^{134}$ lowers the cost of compliance by avoiding restrictions on the progress of the defendant's investigation. It is reasonable for the state to require a defendant to give notice on a set date of his intention to present an alibi defense, and to state the place he claims to have been at the time of the offense. Such disclosure allows the prosecution to develop evidence placing the defendant at the scene of the crime. Notification of such details as the names of witnesses, however, can be provided later without impinging on the state interest in avoiding surprise alibis, provided that such details are disclosed far enough in advance of the presentation of the defendant's case to permit investigation by the state. Indeed, it is in the interest of the defendant to provide such information as early as possible in order to receive reciprocal disclosure from the prosecutor. ${ }^{135}$

\section{Judicial Discretion}

The defendant's cost of compliance may be increased by an inability to locate an alibi witness, the inexperience of defense counsel, or some other unforeseeable event. For that reason it is proper that every alibi notice rule currently in effect gives the trial court some discretion in applying the sanction. ${ }^{138}$ Federal courts consider five factors when determining whether good cause exists to suspend the preclusion sanction: the amount of prejudice to the opposing party that resulted from the failure to disclose; the reason for the failure to disclose; the extent to which the harm of the non-disclosure was mitigated by subsequent events; the weight of other, properly admitted, evidence for and against the defendant;

${ }^{13 s}$ For example, notice could be attached to or be made a part of the indictment, information, bill of particulars, or some other written document ordinarily given by the state to the defendant during the pretrial period.

${ }^{134}$ For an example of such a rule, see Fed. R. CRIM. P. 12.1(c).

138 Reciprocal disclosure of alibi defense evidence is required by Wardius v. Oregon, 412 U.S. 470, 475-76 (1973). See supra note 46.

${ }^{1 s 8}$ See infra Appendix. 
and other factors made relevant by the circumstances of the case. ${ }^{187}$

While the exercise of judicial discretion depends on the facts of each case, and while it is impossible to define with precision acceptable costs to a defendant, two federal cases are illustrative of the issues involved. One court has held that a defendant's refusal to disclose his alibi to his court-appointed attorney prior to trial was not a sufficient reason to avoid the preclusion sanction. ${ }^{138} \mathrm{Re}-$ quiring cooperation with counsel in advance of trial does not place an undue burden on a defendant, and a contrary rule would give the defendant an incentive not to cooperate with his attorney in order to evade the rule. In United States v. Fitts, ${ }^{139}$ defense counsel's assertion that he was not familiar with the federal alibi notice rule was held not to suspend the operation of the sanction, since the prosecutor had demanded alibi witnesses and the rule was mentioned in writing in the demand. Because in federal practice the rule is outlined in the prosecutor's request for alibi notice, ${ }^{140}$ knowledge of the rule-the acquiring of which would otherwise exact a cost of compliance-is available at virtually no cost to the defense.

\section{CoNCLUSION}

Alibi notice rules operate to prevent abuses by defendants presenting alibi defenses and to encourage efficient criminal trials. The preclusion sanction, which excludes alibi evidence when the defendant has not given pretrial notice of his intent to make an alibi defense, is an essential feature of those rules. Nonetheless, the preclusion sanction has been attacked as an unconstitutional de-

137 See United States v. Portillo, 633 F.2d 1313, 1324 (9th Cir. 1980) (finding no prejudice where government's undisclosed witness was permitted to testify), cert. denied, 450 U.S. 1043 (1981); United States v. White, 583 F.2d 899, 901-02 (6th Cir. 1978) (no abuse of discretion where trial court precluded defendant's undisclosed alibi witness from testifying where no good cause for failure to disclose was shown); United States v. Myers, 550 F.2d 1036, 1043 (5th Cir. 1977) (abuse of discretion where trial court permitted government's unnoticed rebuttal alibi witnesses to testify and the testimony was prejudicial to the defendant). Just as the "due diligence" factor in the Berry test, see supra notes 103-05 and accompanying text, is of primary importance in determining the cost to the defendant of discovering evidence prior to trial, the "reason for the failure to disclose" is determinative of the cost to the defendant of complying with the alibi notice rule. See Taliaferro v. State, 295 Md. 376, 390-98, 456 A.2d 29, 37-41, cert. denied, 103 S. Ct. 2114 (1983); supra note 9; infra Appendix.

138 United States v. Barron, 575 F.2d 752, 757-58 (9th Cir. 1978).

189 576 F.2d 837, 839 (10th Cir. 1978).

160 FED. R. CRIM. P. 12.1(a) requires the prosecutor to make written demand upon the defendant for notice of an alibi defense. 
nial of a defendant's right to present a defense. This comment has demonstrated that the preclusion sanction is not imposed at the cost of depriving the defendant of that right, but merely requires the defendant to assert the right in the approved procedural context before trial. Requiring that notice of the intention to present an alibi defense be raised before trial does not place undue costs on the defendant and provides comparatively great benefits to the state.

Lori Ann Irish 


\begin{tabular}{|c|c|c|c|c|c|}
\hline STATE & CITE & $\begin{array}{l}\text { PROSBCUTOR } \\
\text { TRIGGRRED? }\end{array}$ & $\begin{array}{c}\text { APPEN } \\
\text { DOES RULE } \\
\text { EXPLCITLY } \\
\text { PROTECT } \\
\text { DEPBNDANTS } \\
\text { TESTLMONY } \\
\text { FROM } \\
\text { EXCLUSION? }\end{array}$ & $\begin{array}{l}\text { DIX } \\
\text { DOES RULE } \\
\text { EXPLICITLY } \\
\text { ALLOW } \\
\text { EXCLUSION } \\
\text { OF OTHRR } \\
\text { WITNESSES' } \\
\text { TESTIMONY? }\end{array}$ & COMMENTS \\
\hline Ariz. & $\begin{array}{l}\text { ARIZ. R. CRIM } \\
\text { P. 15.2(b); } 15.7\end{array}$ & No & No & Yes & $\begin{array}{l}\text { Court may order disclosure } \\
\text { or continuance, hold witness, } \\
\text { party, or counsel in con- } \\
\text { tempt, or declare a mistrial. } \\
\text { If the defendant fails to dis- } \\
\text { close, inter alia, his alibi } \\
\text { defense, prosecutor "need } \\
\text { make no further disclosure } \\
\text { except material or informa- } \\
\text { tion which tends to mitigate } \\
\text { or negate defendant's guilt." } \\
\text { ARIz. R. CRIM. P. 15.7(b). }\end{array}$ \\
\hline Ark. & $\begin{array}{l}\text { ARK. R. CRIM. } \\
\text { P. } 18.3,19.7\end{array}$ & Yes & No & Yes & $\begin{array}{l}\text { Court may order discovery, } \\
\text { or continuance, exclude non- } \\
\text { disclosed material, order ap- } \\
\text { propriate court sanctions } \\
\text { against defendant or counsel } \\
\text { for wilful violations. }\end{array}$ \\
\hline Colo. & $\begin{array}{l}\text { Colo. R. CRIM. } \\
\text { P. } 121.1\end{array}$ & Yes & No & Yes & \\
\hline Conn. & $\begin{array}{l}\text { ConN. SuPER. } \\
\text { CT. R. §§ 762- } \\
767\end{array}$ & Yes & Yes & Yes & \\
\hline
\end{tabular}

D.C. D.C.R. Crum. Yes Yes Yes P. 12.1

Fla. FLA. R. Crm. Yes

Yes

Yes

P. 3.200

$\mathrm{Hz}$ - HaWaII R Pz- No

Yes

Yes

waii NAL P. 12.1

Idaho IDAHo CoDE \& Yes

Yes

Yes

IIl. ILL. SuP. CT.

Yes

No

Yes

R. 413(d), 415(g)

Ind. IND. CoDE

No

No

Yes

ANN. § 35-36-

4-1 to $-4-3$

(Burns 1983) 


\begin{tabular}{|c|c|c|c|c|c|}
\hline STATE & CITE & $\begin{array}{l}\text { PROSECUTOR } \\
\text { TRIGGERED? }\end{array}$ & $\begin{array}{l}\text { DOES RULL } \\
\text { EXPLICITLY } \\
\text { PROTECT } \\
\text { DEFENDANTS } \\
\text { TESTIMONY } \\
\text { FROM } \\
\text { EXCLUSION? } \\
\end{array}$ & $\begin{array}{l}\text { DOES RULE } \\
\text { EXPLICTILY } \\
\text { ALLOW } \\
\text { EXCLUSION } \\
\text { OF OTHER } \\
\text { WITNESSES } \\
\text { TESTIMONY? }\end{array}$ & COMMENTS \\
\hline Iowa & $\begin{array}{l}\text { Iowa R. CRIM. } \\
\text { P. 10(11a), } \\
\text { 10(11d) }\end{array}$ & No & Yes & Yes & $\begin{array}{l}\text { Court may order delay or } \\
\text { continuance. }\end{array}$ \\
\hline Kan. & $\begin{array}{l}\text { Kan. Stat. } \\
\text { ANN. § 22-3218 } \\
\text { (1981) }\end{array}$ & No & Yes & Yes & \\
\hline La. & $\begin{array}{l}\text { LA. CODE } \\
\text { CRIM. PROC. } \\
\text { ANN. art. 9727 } \\
\text { (West 1981) }\end{array}$ & Yes & Yes & Yes & \\
\hline Me. & $\begin{array}{l}\text { ME. R. CRIM. } \\
\text { P. } 16 \text { A(b) }\end{array}$ & Yes & No & No & $\begin{array}{l}\text { Exclusion of witnesses may } \\
\text { be permissible, but the rule } \\
\text { is not explicit: for defen- } \\
\text { dant's failure to notify, the } \\
\text { "court may take appropriate } \\
\text { action." }\end{array}$ \\
\hline Md. & $\begin{array}{l}\text { Mo. ANN. } \\
\text { CodE art. 9B } \\
\text { Rule 741(d)(3) } \\
\text { f,g (1983) }\end{array}$ & Yes & No & Yes & $\begin{array}{l}\text { Court may order continuance, } \\
\text { grant a mistrial, order more } \\
\text { discovery or strike testimony } \\
\text { already given on undisclosed } \\
\text { matter, or any other neces- } \\
\text { sary order. }\end{array}$ \\
\hline
\end{tabular}

Mass. Mass. $R$.

CrIM. P.

Yes Yes Yes

14(b)(1)

Mich. Mick. Comp.

LAWS ANN.

§ 768.20,

738.21 (West

1982)

Minn. Mins. R.

Yes

No

Yes

CRIM. P. 9.02, subd. 1(3)(a),

(c), 9.03 subd.

8

Yes Yes

In People v. Merritt, 396

Mich. 67, 83-88, 238 N.W.2d

31, 38-41 (1976), the Michigan Supreme Court held that the rule must be interpreted to protect defendants' testimony from exclusion. Though the court ruled on a prior version of the current rule, its reasoning applies equally to the current rule.

Exclusion of witnesses may be permissible, but the rule is not explicit; court may order discovery or continuance, "or enter such order as it deems just."

Miss. Miss. UnIForm Yes Yes Yes Court may order continuance, limit discovery by non-complying party or find noncomplying attorney in contempt. 


\begin{tabular}{|c|c|c|c|c|c|}
\hline STATE & CITE & $\begin{array}{l}\text { PROSECUTOR } \\
\text { TRIGGRRED? } \\
\end{array}$ & $\begin{array}{c}\text { DOES RULE } \\
\text { EXPLICITLY } \\
\text { PROTECT } \\
\text { DEFENDANTS } \\
\text { TESTIMONY } \\
\text { FROM } \\
\text { EXCLUSION? } \\
\end{array}$ & $\begin{array}{c}\text { DOES RULE } \\
\text { EXPLICITLY } \\
\text { ALLOW } \\
\text { EXCLUSION } \\
\text { OF OTHER } \\
\text { WITNESSES' } \\
\text { TESTDMONY? } \\
\end{array}$ & COMMENTS \\
\hline Mo. & $\begin{array}{l}\text { Mo. R. CRIM. } \\
\text { P. } 25.05(\mathrm{~A})(5) \text {, } \\
25.16\end{array}$ & Yes & No & Yes & $\begin{array}{l}\text { Court may order discovery } \\
\text { continuance, or exclusion. }\end{array}$ \\
\hline Mont. & $\begin{array}{l}\text { Mont. CODE } \\
\text { ANN. § 46-15- } \\
301 \text { (1983) }\end{array}$ & No & No & Yes & \\
\hline Nev. & $\begin{array}{l}\text { Nev. Rev. } \\
\text { Stat. } \\
\S 174.087 \\
(1981)\end{array}$ & No & Yes & Yes & \\
\hline N.H. & $\begin{array}{l}\text { N.H. SuPER. } \\
\text { CT. R. } 100\end{array}$ & No & Yes & Yes & \\
\hline N.J. & $\begin{array}{l}\text { N.J. R. CRIM. } \\
\text { Prac. 3:11-1, - } \\
2\end{array}$ & Yes & No & Yes & $\begin{array}{l}\text { Court may "make such other } \\
\text { order or grant such adjourn- } \\
\text { ment as the interest of jus- } \\
\text { tice requires." }\end{array}$ \\
\hline N.M. & $\begin{array}{l}\text { N.M. R. CRIM } \\
\text { P. } 32\end{array}$ & Yes & Yes & Yes & \\
\hline N.Y. & $\begin{array}{l}\text { N.Y. CRIM. } \\
\text { Proc. LAW } \\
\text { § } 250.20 \\
\text { (McKinney } \\
\text { 1982) }\end{array}$ & Yes & Yes & Yes & $\begin{array}{l}\text { Under People v. Rakiec, } 289 \\
\text { N.Y. } 306,308-09,45 \text { N.E.2d } \\
812 \text { (1942), the rule is inter- } \\
\text { preted to protect the defen- } \\
\text { dant's testimony from exclu- } \\
\text { sion. If the court, in its } \\
\text { discretion, decides to hear } \\
\text { defendant's alibi testimony } \\
\text { without notice, it must, upon } \\
\text { application of prosecution, } \\
\text { grant an adjournment not in } \\
\text { excess of three days. }\end{array}$ \\
\hline N.D. & $\begin{array}{l}\text { N.D. R. CRIM. } \\
\text { P. } 12.1\end{array}$ & No & Yes & Yes & \\
\hline Ohio & $\begin{array}{l}\text { OHIO R. CRIM. } \\
\text { P. } 12.1\end{array}$ & No & No & Yes & \\
\hline Okla. & $\begin{array}{l}\text { OKLA. STAT. } \\
\text { ANN. tit. } 22 \text {, } \\
\S 585 \text { (West } \\
1969 \text { ) }\end{array}$ & No & No & No & $\begin{array}{l}\text { Court may grant postpone- } \\
\text { ment for state to investigate } \\
\text { the evidence. }\end{array}$ \\
\hline
\end{tabular}

Or. OR. Rev. Stat. No

No Yes

§ 13.5455 (1981)

Pa. PA. R. CRIM. No

Yes

Yes

$P$.

$305(C)(1)(a)$,

(d) ment for state to investigate evidence.

Court may grant a continuance for investigation, or "such other order as the interests of justice require." 


\begin{tabular}{|c|c|c|c|c|c|}
\hline STATE & CITE & $\begin{array}{l}\text { PROSECUTOR } \\
\text { TRIGGERED? }\end{array}$ & $\begin{array}{c}\text { DOES RULE } \\
\text { EXPLICITLY } \\
\text { PROTECT } \\
\text { DEFENDANTS } \\
\text { TESTIMONY } \\
\text { FROM } \\
\text { EXCLUSION? }\end{array}$ & $\begin{array}{c}\text { DOES RULE } \\
\text { EXPLICTTLY } \\
\text { ALLOW } \\
\text { EXCLUSION } \\
\text { OF OTHER } \\
\text { WTTNESSES' } \\
\text { TESTIMONY? }\end{array}$ & COMMENTS \\
\hline R.I. & $\begin{array}{l}\text { R.I. R. CRIM. } \\
\text { P. } 16(c),(\text { i) }\end{array}$ & Yes & No & Yes & $\begin{array}{l}\text { The rule is prosecutor trig- } \\
\text { gered, but only applies if } \\
\text { defendant first moves for dis- } \\
\text { covery. Court may order con- } \\
\text { tinuance or more discovery or } \\
\text { make any other necessary or- } \\
\text { der. }\end{array}$ \\
\hline
\end{tabular}

S.C. S.C. R. og

Practice in

Yes

Cir. CT. 103(e)

S.D. S.D. CoDIFIED

LAwS ANn. §§

23A-9-1 to -6

(1979) (Rule

12.1(a))

Tenn. Tenn. $R$.

CrIm. P. 12.1

Utah UTAH CODE

ANN. \& 77-14-2

(1982)

Vt. VT. R. CRIM.

P. 12.1

Va. VA. Sur. CT.

Yes

No

R. 3A:

14(c)(2),

$14(\mathrm{c})(8)$

No

Yes

Yes
Yes Yes

Yes Yes

Yes Yes Yes

Yes Yes Yes

Yes

Yes

The reporter's notes to the rule provide for the explicit protection of the defendant's testimony from exclusion.

No The rule is prosecutor-triggered, but only applies if defendant moves for discovery. If not complied with, court shall permit discovery or inspection of materials not previously disclosed. 


\begin{tabular}{|c|c|c|c|c|c|}
\hline & & PROSBCUTOR & $\begin{array}{l}\text { DOES RULE } \\
\text { EXPLICITLY } \\
\text { PROTECT } \\
\text { DEFENDANT'S } \\
\text { TESTTMONY } \\
\text { FROM }\end{array}$ & $\begin{array}{c}\text { DOES RULE } \\
\text { EXPLICITLY } \\
\text { ALLOW } \\
\text { EXCLUSION } \\
\text { OF OTHER } \\
\text { WITNESSES' }\end{array}$ & \\
\hline TATE & CrTE & TRIGGERED? & EXCLUSION? & TESTMONY? & COMMENTS \\
\hline
\end{tabular}

Wash. Wash. R. CrIM. P. 4.7

Yes

No

No

Court may order discovery or continuance, dismiss action, or make any order it deems just; wilful violation may subject counsel and defendant to appropriate sanctions by court. See State v. Nelson, 14 Wash. App. 658, 661, 545 P.2d 36, 38 (1975) (in view of the availability of contempt sanction, and of a defendant's continuing ability to "purge" himself by disclosing alibi information, preclusion "has not as yet been applied and may never be"). In 1973 , rule 4.7 replaced a statute that did explicitly allow preclusion. See State v. Grant, 10 Wash. App. 468, 469 n.1, 519 P.2d 261, 262 n.1 (1974).
W. W. VA. R.

Va. Crim. P. 12.1

Wis. Wis. R. CRIM. P. 971.23(8)

Wyo. Wyo. R. CRIM. P. 16.1
Yes

No

Yes
Yes

No

Yes
Yes

Yes

Yes 